\title{
THE IMPACT OF NON TIDAL SWAMP LAND CONVERSION ON CHANGES OF FARMERS' INCOME IN SOUTH SUMATRA PROVINCE, INDONESIA
}

\author{
Purbiyanti E., Yazid M., Arbi M., Adriani D., Hamzah M., Kurniawan H. \\ Faculty of Agriculture, University of Sriwijaya, Indonesia \\ *E-mail: erni.purbiyanti@fp.unsri.ac.id
}

\begin{abstract}
The construction of the Kayu Agung-Palembang-Betung (abbreviated as Kapal Betung) toll road has an impact on changes in the income of rice farmers. The aim of this research was to analyze the changes of farmers' income after converting their non-tidal swamp land to toll road. The research method used in this study is the survey method. In this study the random sampling method used by incidentally. The samples were 60 persons. There was a change in farmers' income before and after converting their rice fields. The livelihoods of postconversion farmers also experience an increase in the variety of occupations. Even though the value of farmers' income after conversion of paddy fields has increased; but this condition needs special attention for policy makers, because of the decreasing number of farmers who will have an impact on national food sovereignty.
\end{abstract}

\section{KEY WORDS}

Farmers' income change, conversion, non-tidal swamp land, farmer.

Land is a very important resource for farmers in conducting farming activities. Large land will further increase the hopes of farmers to live properly. As the population increases, the existence of land, especially agricultural land, is increasingly threatened. The demand for land for development is so strong, while the land area is not increasing or limited. So far, agricultural land has a low land value compared to the allocation of non-agricultural land, consequently agricultural land will continuously experience land conversion to nonagricultural. Even though agricultural land (rice fields) besides having economic value as a buffer for food needs, also ecological functions such as regulating the water system, absorption of carbon in the air and so on (Dewi \& Rudiarto, 2013)

The population of Indonesia every year experiences positive growth (https://data.worldbank.org). The growth rate is always positive almost every year, such as in 2016 amounting to $1.13 \%$ and 2017 at $1.09 \%$, and data shows a population increase of 325,488 people between 2014 and 2017 in the Province of South Sumatra, it meaning that the Province of South Sumatra is an area that has increased. Ogan Komering llir Regency is the largest regency in its territory, with an area of $18,359.04 \mathrm{~km}^{2}$ or around $20,044 \%$ of the total area of the entire Province of South Sumatra showing an increase in the population in the area during the period 2014 to 2017, which amounted to 32,940 people. The following table shows the amount of population growth per year by the South Sumatra Provincial Statistics Agency in 2018 in each regency/city in South Sumatra.

The development of human life always demands that things become easier and faster, from various aspects, starting from information technology and infrastructure, both of which require continuous development to provide convenience for each individual, especially in terms of travel time. Infrastructure development is a development that can be seen in real or material terms. The existence of a development carried out has an influence on aspects of life that exist within the community. Infrastructure development in particular, has more influence on socio-economic conditions that make a region and its population more developed (Dewi, Kastolani, \& Eridiana, 2016).

The construction of road infrastructure is one of the main priorities in the Indonesian government agenda regulated in the 2015-2019 Directorate of Land Transportation Directorate General of Land Transportation, which explains that the purpose of transportation development in general is to improve transportation services in an efficient, effective, reliable, 
quality and safe at affordable prices. Infrastructure is a major need to support the activities of the region and the city so that the public sector and the private sector can run well. In addition, it is an effort to offset the growth in the number of vehicles due to the increasing population growth (Laras \& Mei, 2017).

Currently on the island of Sumatra the government plans to build a toll road megaproject that will connect Aceh to Lampung. In South Sumatra Province itself is planned to build eight toll roads with a total length of 810 kilometers. With details of the Pematang Panggang-Kayu Agung toll road 85 kilometers, Kayu Agung-Palembang-Betung 112 kilometers, Betung-Tempino-Jambi 191 kilometers, Palembang-TAA 70 kilometers, Lubuk Linggau-Curup-Bengkulu 95 kilometers, Muara Enim-Lubuk Linggau 125 kilometers , Indralaya-Muara Enim 110 kilometers, and Palembang-Indralaya 22 kilometers. Of the eight projects, only three have entered the development stage where one of them has been operating, namely the Palembang-Indralaya Toll Road or Palindra'.

Kayu Agung-Palembang-Betung (abbreviated as Kapal Betung) Toll Road is a toll road that stretches for 112 kilometers which will connect the city of Kayu Agung with Palembang to Betung Banyuasin district, South Sumatra Province. Construction of this toll road began in 2016 and is expected to be completed in 2019. The construction of this toll road has resulted in land acquisition in Kayu Agung City and its surroundings, especially in Arisan Buntal Village, Kayu Agung Sub-District, Ogan Komering llir Regency. In this village hundreds of hectares of paddy fields were sacrificed for the implementation of toll road construction, this resulted in changes in the livelihoods of the people in this village due to land acquisition that occurred. In addition, indirectly the construction of this toll road will result in a reduction in agricultural land in South Sumatra generally.

The Ministry of Agrarian and Spatial Planning/National Land Agency efforts to control the conversion of agricultural land to non-agricultural food crops effectively in Law No. 41 of 2009 concerning the Protection of Sustainable Food Agricultural Land (PLP2B) and its Supporting Government Regulations. But the fact is that the conversion of agricultural land to non-agriculture continues. This is a future challenge for the sustainability of agricultural production in realizing food security. The means of protection given to farmers starting from the upstream to downstream processes and trading systems must be considered and further developed (https://www.atrbpn.go.id). Farmers whose land is included in land acquisition for toll road development do not all want their land to be compensated by the developer. The development of infrastructure that benefits many people has made farmers have to give up their land. Farmers' perceptions of the construction of toll road projects are influenced by both inside and outside the farmers. Farmers whose land is automatically converted also lose their jobs, with the compensation received making farmers have new jobs switching to non-agriculture. Even though there are also farmers who use substitute products to buy land in other places to still be able to farm. Indirectly this affects the income level of farmer households.

Based on the background of the construction of the Kapal Betung Toll Road which requires land acquisition so that it can have an impact on the farming community, further research can be conducted on how changes in the level of welfare of farmers based on income before and after the construction of the Kapal Betung Toll Road.

\section{METHODS OF RESEARCH}

This research was conducted in Arisan Buntal Village which is precisely located in Ogan Komering llir District and Kayu Agung District. This research was conducted in October 2018 to completion. This location was determined purposively because the construction of the Kapal Betung toll road passed through the village. There were many farmers whose fields were affected by toll road construction in this village.

The research method used in this study is the survey method. The survey method is one method in social research. Survey research is a study using the same structured

\footnotetext{
${ }^{1}$ Sumatera Ekspres newspaper. October 16, 2018. Five Tolls Stagnate.
} 
questions in each person, and then all answers obtained from each respondent are recorded, processed, and analyzed.

In this study the random sampling method used by incidentally. The reason for this sample technique is because the sampling members were obtained through the village head's data about farmers whose was converted their land and then found by the researcher incidentally, whom could be met at the time when the researcher were collecting the primary data. The samples were 60 persons.

The data used in this study are primary data and secondary data. Primary data obtained by data collection through questionnaires obtained directly through interviews and discussions with respondents, while secondary data is data obtained from various literature, theories, opinions of experts, the Central Statistics Agency (BPS), etc.

To answer the purpose of this study using paired T-test and data processed using Microsoft Excel 2016 and IBM SPSS Statistics 25. Paired Sample T-Test or paired t_test test is part of parametric statistics used to find out whether there are differences in the average of two samples in pairs or the same sample but have two data. In this case, there is a change in household income received by farmers after the acquisition of agricultural land for the Kapal Betung Toll Road. The hypotheses and rules of decision can be written as follows:

Ho: There was no difference in income of farmer households before and after converting their non-tidal swamp land.

$\mathrm{Ha}$ : There was a difference in income of farmer households before and after converting their non-tidal swamp land.

Value of sig (2-tailed) $>$ a then accept Ho.

Value of Sig (2-tailed) value $\leq$ a then reject Ho.

Accept Ho means that the household income of the farmer before the land acquisition process is not significantly different from the household income after land acquisition.

Reject Ho means that the household income of the farmer before the land acquisition process is significantly different from the area of farmer's land ownership after land acquisition.

\section{RESULTS AND DISCUSSION}

Characteristics of respondents of paddy farmers affected by conversion of their land to Kapal Betung toll road in Arisan Buntal Village descriptively include: (1) age, (2) education, (3) land area and land status, (4) number of dependents, and (5) several of works.

Respondents taken in this study had very varied ages, ranging from age 25 to 85 years and above. Based on the table below, it can be seen that the respondents who carry out rice farming activities in Arisan Buntal Village Kayuagung Subdistrict, Ogan Komering Ilir Regency are mostly in the age group of 46 to 65 years as many as 30 people or 50 percent and belong to the productive age group, while the highest age group the second is the age group of 25 to 45 years as many as 24 people or 40 percent. While the age group of respondents is no longer productive, because the older the age of farmers, the lower the performance of farmers is in the age group of 66 to 85 as many as 6 people or 10 percent of all respondents totaling 60 people.

Table 1 - Age Distribution of Respondents of Rice Farmers

\begin{tabular}{cccc}
\hline No & Age Class Interval & Number of People & Percentage (\%) \\
\hline 1. & $25-45$ & 24 & 40,00 \\
2. & $46-65$ & 30 & 50,00 \\
3. & $66-85$ & 6 & 10,00 \\
\hline & Total & 60 & 100,00 \\
\hline
\end{tabular}

The education level of a farmer affects the way decisions are made or a problem in his activities, not only in terms of farming education, it will also influence the farmers' strategy in dealing with things. In this case the education level of the respondents in Arisan Buntal Village has an education level starting from non-school, graduating from elementary school 
(SD) graduating from junior high school (SMP), graduating from high school (SMA) and Diploma (D2). Based on the table below, the education level of respondents is still relatively low; the highest level of education is as many as 33 people with a percentage of 55 percent. Then followed by 14 junior high school education with a percentage of 23 percent, followed by high school, diploma and graduate education with details of 9 high school students, 1 Diploma 2 and 1 Bachelor with a percentage of 18 percent and no school as much as 2 people with a percentage of 4 percent of all respondents totaling 60 people.

Table 2 - Farmers' Education Distribution

\begin{tabular}{cccc}
\hline No & Farmers' Level of Education & Number of People & Persentage (\%) \\
\hline 1. & No school & 2 & 4,00 \\
2. & Elementary school & 33 & 55,00 \\
3. & Junior high school & 14 & 23,00 \\
& High School and College & 11 & 18,00 \\
\hline & Total & 60 & 100,00 \\
\hline
\end{tabular}

The area of land is the total land owned by the farmer which is used as a source of farmer's livelihood and ownership status of his own land or rent. The area cultivated by respondents in Arisan Buntal Village Kayuagung Subdistrict is in the range of 0.5 hectares to 10 hectares. Based on the table below, it is known that the area of land owned by the respondents is the largest area of land is lahan 1 hectare, which is 72 people with a percentage of 72 percent. Then followed by land area of $1>-\leq 2$ hectares, amounting to 9 people with a percentage of 15 percent and farmer's land area> 2 - 3 hectares, amounting to 6 people with a percentage of 10 percent and $>3$ hectares totaling 2 people with a percentage of 3 percent.

Table 3 - Land area

\begin{tabular}{cccc}
\hline No & Area of Farmer's Land $(\mathrm{Ha})$ & Number of people & Persentage $(\%)$ \\
\hline 1. & $\leq 1$ & 43 & 72,00 \\
2. & $1>-\leq 2$ & 9 & 15,00 \\
3. & $>2-\leq 3$ & 6 & 10,00 \\
4. & $>3$ & 2 & 3,00 \\
\hline & Total & 6 & 100,00 \\
\hline
\end{tabular}

With the land area owned by the respondent which is a private property or in other words the land ownership status is their own. In this case the respondents use land that they have to do farming that will generate income for the respondents who will be very useful to meet the needs ranging from clothing, shelter and food. Based on the table below, it is known that the land status used by respondents in Arisan Buntal Village, Ogan Komering llir Regency, is private or self-owned land, which amounts to 100 percent. This means that the status of the respondent's land in Arisan Buntal Village, Kayuagung Subdistrict, Ogan Komering llir District, in this study is self-owned land.

Table 4 - Land Status

\begin{tabular}{cccc}
\hline No. & Farmer's Land Status & Number of People & Persentage (\%) \\
\hline 1. & One's own & 60 & 100,00 \\
\hline & Total & 60 & 100,00 \\
\hline
\end{tabular}

The number of respondent's family members is the total number of people who enter one blood where these family members are people who are dependent on the head of the family and in one house which in this case includes children, wives, and brothers who are borne by the farmer for example. Based on the table below, it is known that the number of family members of respondents in Arisan Buntal Village, namely respondents have families or dependents between 5 to 6 , amounting to 13 farmers with a percentage of 22 percent, while respondents who have dependents 3 to 4 are 25 people with a percentage of 42 
percent and respondents who have 1 to 2 dependents number 22 people with a percentage of 36 percent.

Table 5 - Number of Respondents' Dependents

\begin{tabular}{cccc}
\hline No & Number of Farmers' Family Members & Number of People & Persentage $(\%)$ \\
\hline 1. & $1-2$ & 22 & 36,00 \\
2. & $3-4$ & 25 & 42,00 \\
3. & $5-6$ & 13 & 22,00 \\
\hline & Total & 6 & 100,00 \\
\hline
\end{tabular}

Based on the table below, it can be seen that the respondent's work in Arisan Buntal Village Kayuagung Sub-District before the construction of the toll road was dominated by farmers with 54 people or 88 percent, then civil servants as many as 3 people or 5 percent and traders as many as 2 or 3 percent and Labor and Security respectively 1 person or 2 percent of the entire population.

Table 6 - Occupation of Respondents in Arisan Buntal Village before Development

\begin{tabular}{cccc}
\hline No & Livelihood & Number of people & Persentage (\%) \\
\hline 1. & Farmer & 54 & 88,00 \\
2. & Civil servants & 3 & 5,00 \\
3. & Traders & 2 & 3,00 \\
4. & Laborer & 1 & 2,00 \\
5. & Security & 1 & 2,00 \\
\hline & Total & 60 & 100,00 \\
\hline
\end{tabular}

Based on the table below it is known that the types of work of Respondents in Arisan Buntal Village Kayuagung Subdistrict, Ogan Komering llir Regency increased which initially only 5 to 12 kinds or 7 new types of work, namely drivers, wooden shifters, fishermen, mechanics, motorcycle taxis, oil palm employees, and chicken farmers. Farmers (not working) as many as 20 people with a percentage of 33 percent, 3 civil servants with a percentage of 5 percent, Padagang as many as 7 people with a percentage of 11 percent, Labor as many as 11 people with a percentage of 18 percent, Security as many as 3 percent, Driver as many as 3 people with a percentage of 5 percent, wooden swabs as much as 1 person with a percentage of 2 percent, fishermen as many as 7 people with a percentage of 12 percent, mechanics as many as 1 person with a percentage of 2 percent, ojek as many as 1 percent with a percentage of 3 percent, and chicken farmers as much as 1 person with a percentage of 2 percent.

Table 7 - Occupation of Respondents in Arisan Buntal Village after Development

\begin{tabular}{rccc}
\hline No & Livelihood & Number of people & Persentage (\%) \\
\hline 1. & Farmer (Not Working) & 20 & 33,00 \\
2. & Civil Servants & 3 & 5,00 \\
3. & Traders & 7 & 11,00 \\
4. & Laborer & 11 & 18,00 \\
5. & Security & 3 & 5,00 \\
6. & Driver & 3 & 5,00 \\
7. & Wood Slider & 1 & 2,00 \\
8. & Fisherman & 7 & 12,00 \\
9. & Mechanic & 1 & 2,00 \\
10. & Taxibike & 1 & 2,00 \\
11. & Palm Employees & 2 & 3,00 \\
12. & Chicken Farmer & 1 & 2,00 \\
\hline
\end{tabular}

Impact of Paddy Field Conversion on Changes in Farmers' Income. Based on the results of interviews, the majority of farmers in Arisan Buntal Village experienced crop failures and crop failures since the last 5-6 years due to paddy fields that were always flooded. This was made worse by the construction of the Kapal Betung toll road (Figure 1). 
Based on (Sjarkowi, 2014), it is known that there are three main factors that result in changes in surface water behavior and also the volume of runoff water, namely: (1) Road facilities are constructed with a position to divide the swamp which causes the direction of runoff to be blocked; (2) The canal facilities and road network within the plantation concession are increasingly fully developed; and (3) Increasingly densely populated facilities for settlements and permanent walls built on hoarding land. This condition is exacerbated by the construction of toll roads with minimal 'sodetan' / artificial canals, so that paddy fields around the toll road are increasingly inundated.

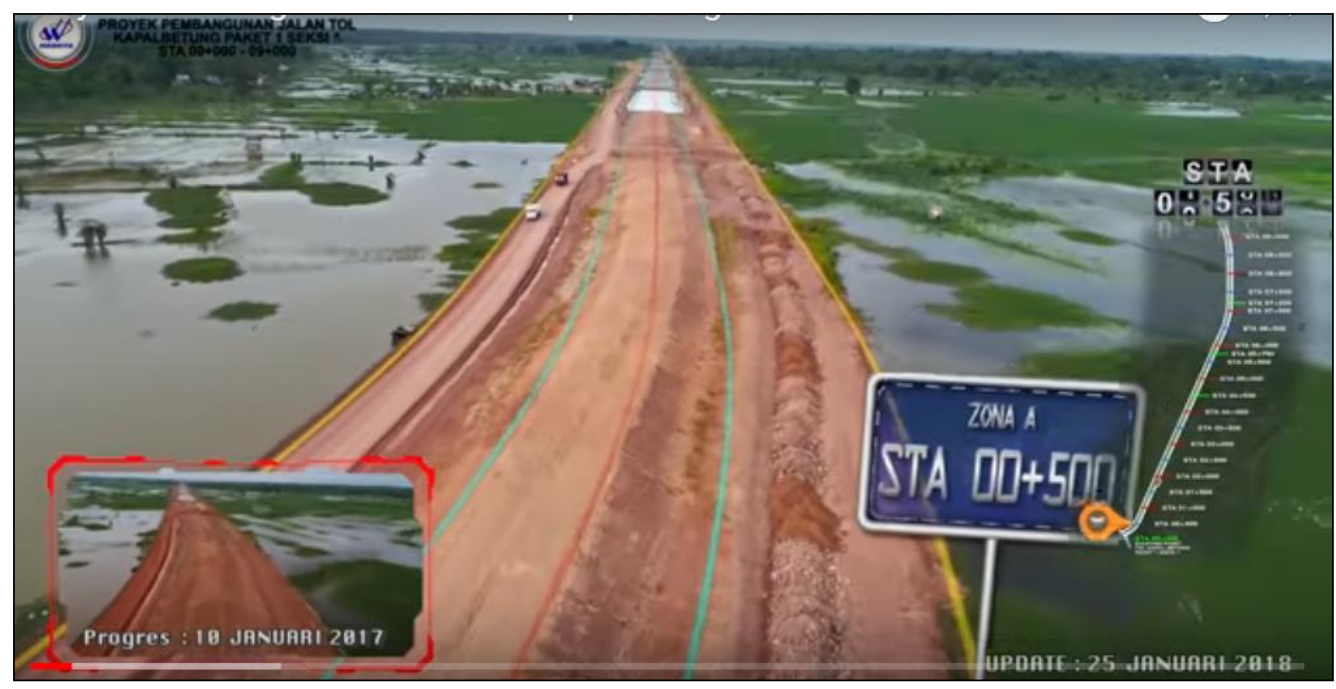

Figure 1 - Construction of the Kapal Betung toll road and flooded rice fields

Conversion of paddy fields has a negative impact on the decline in income sourced from rice farming (Table 3.8). Based on the table below, it is known that the average income of farmers affected by land acquisition originating from rice farming is higher than the income of rice farming after converting part or all of their rice fields. Revenues sourced from outside the farm have increased. This is reasonable because rationally farmers will look for other jobs to meet their family's needs. Farmers already have a fairly good institution, especially in selling their crops. This is consistent with the research of (Husin, Yulius, Adriani, \& Antoni, 2017) which concludes that farmers involved in institutions have more high income than when they are not incorporated into an institution.

Table 8 - Average Household Income

\begin{tabular}{cccc}
\hline No & Source of Income & Prior Income & After Income \\
\hline 1. & Farming & Rp 16,227,781.00 & Rp 11,726,075.00 \\
2. & Overseas Farming & Rp 31,416,000.00 & Rp 43,155,676.00 \\
\hline & Total & $R p ~ 47,643,781.00$ & Rp 54,881,751.00 \\
\hline
\end{tabular}

To test whether there is a difference between income before and after conversion of paddy fields, a t-test is carried out as the results are summarized in Table 3.9. Based on these results, the value of $t$ arithmetic is $|-2,122| t$ and the value of $t$ table is 0.05 (2-sided) of 1,677 . The value of $t$ count $>t$ table, then the decision criterion is Reject Ho, which means there is a difference between the income of farmers before and after converting their paddy fields. Besides being seen from the value of $t$, the significance level of 0.03850 .05 can also be used as an indicator to deduce the decision criteria. This means that there is a difference between the total income of former landowners before and after the conversion of paddy fields. This condition is in accordance with the facts in the field which shows the more varied types of work after converting paddy fields as shown in Table 3.7. Even though the income of farmers after conversion of paddy fields has increased; but this condition needs special attention for policy makers, because of the decreasing number of farmers who will have an 
impact on national food sovereignty. The condition of the swampy land in Ogan Komering llir has experienced many technical obstacles, so that various strategies need to be improved in developing innovative services and businesses (Sitepu, Sjarkowi, Yunita, \& Sari, 2018)). The government must make efforts to overcome the technical obstacles faced by farmers, also implement innovative policies in an effort to increase income the farmer.

Table 9 - T-Test Results

\begin{tabular}{|c|c|c|c|c|c|c|c|c|c|}
\hline & \multirow{3}{*}{$\mathrm{n} / \mathrm{n}$} & \multicolumn{5}{|c|}{ Paired Differences } & \multirow{3}{*}{$t$} & \multirow{3}{*}{$\mathrm{df}$} & \multirow{3}{*}{$\begin{array}{l}\text { Sig. } \\
(2- \\
\text { tailed })\end{array}$} \\
\hline & & \multirow[t]{2}{*}{ Mean } & \multirow[t]{2}{*}{ Std. Deviation } & \multirow{2}{*}{$\begin{array}{l}\text { Std. Error } \\
\text { Mean }\end{array}$} & \multicolumn{2}{|c|}{$\begin{array}{l}\text { 95\% Confidence Interval of the } \\
\text { Difference }\end{array}$} & & & \\
\hline & & & & & Lower & Upper & & & \\
\hline $\begin{array}{c}\text { Pair } \\
1\end{array}$ & $\begin{array}{c}\text { Prior } \\
\text { Income- } \\
\text { After } \\
\text { Income }\end{array}$ & -14277824.23850 & 52122156.07108 & 6728941.41439 & -27742404.90812 & -813243.56888 & -2.122 & 59 & .038 \\
\hline
\end{tabular}

\section{CONCLUSION AND SUGGESTIONS}

The construction of the Kapal Betung toll road has an negative impact on changes in the income of rice farmers. There was a change in farmers' income before and after converting their rice fields. The livelihoods of post-conversion farmers also experience an increase in the variety of occupations. Even though the value of farmers' income after conversion of paddy fields has increased; but this condition needs special attention for policy makers, because of the decreasing number of farmers who will have an impact on national food sovereignty. The government must make efforts to overcome the technical obstacles faced by farmers, also implement innovative policies in an effort to increase income the farmer.

\section{ACKNOWLEDGEMENTS}

Acknowledgments to those who helped and gave suggestions for the completion of this research. Especially to the Chancellor of Sriwijaya University through the Institute for Research and Community Service, which has funded this research through the PNBP of Sriwijaya University of Competitive Grant Research Scheme on 2018.

\section{REFERENCES}

1. Dewi, N. K., \& Rudiarto, I. (2013). Identifikasi Alih Fungsi Lahan Pertanian and Kondisi Sosial Ekonomi Masyarakat Daerah Pinggiran di Kecamatan Gunungpati Kota Semarang, 1, 175-188.

2. Dewi, R., Kastolani, W., \& Eridiana, W. (2016). Pengaruh Konversi Lahan pada Pembangunan Jalan Tol Cisumdawu terhadap Perubahan Status Sosial and Ekonomi Petani di Kecamatan Rancakalong Kabupaten Sumedang, 4.

3. Husin, L., Yulius, Adriani, D., \& Antoni, M. (2017). Effect of Different Rubber Market System on Farmer's Income in South Sumatra Province, Indonesia. Russian Journal of Agriculture and Socio-Economic, 11(November), 257-262.

4. Laras, H., \& Mei, E. T. W. (2017). Persepsi Masyarakat terhadap Pembangunan Jalan Tol Bekasi-Cawang-Kampung Melayu (Becakayu). Jurnal Bumi Indonesia, vol. 6, 1-10. Retrieved from http://lib.geo.ugm.ac.id/ojs/index.php/jbi/issue/view/24

5. Sitepu, M. F., Sjarkowi, F., Yunita, \& Sari, S. N. (2018). Chayanov's Syndrome as Faced by 'BAP' Agribusiness Corporation andthe Peasant Communities Living in and Nearby the Forestry Estate Concession. Russian Journal of Agriculture and Socio-Economic, 6(June), 46-52. https://doi.org/10.18551/rjoas.2018-06.04

6. Sjarkowi, F. (2014). Agro-ekosistem Lahan Basah Lestari: Titah Inovasi Kedaulatan Pangan and Kesejahteraan Masyarakat Agraris. Palembang: Baldad Grafiti Press. 